Makalah: disampaikan pada mata kuliah Pengembangan Model Pembelajar IPS. UPI, 2015.

\title{
TEORI BELAJAR DAN MODEL PENERAPANNYA DALAM PEMBELAJARAN
}

\author{
Suharli \\ Dosen FKIP-Universitas Samawa Sumbawa Besar-NTB \\ suharli@fkip.universitassamawa.ac.id
}

\begin{abstract}
Abstrak
Teori dan model pembelajaran merupakan salah satu kunci keberhasilan proses pembelajaran yang dilakukan oleh tenaga pendidik. Keberhasilan tersebut juga tidak terlepas dari kemampuan tenaga pendidik dalam merancang teori dan model pembelajaran tersebut menjadi lebih sistimatis untuk mencapai tujuan belajar yang telah ditetapkan. Penggunaan bahan-bahan pustaka yang relevan dilakukan sebagai langkah dalam menganalisis hasil dalam tulisan ini yaitu melalui proses penyeleksian sumber relevan, melakukan refleksi, menganalisis, dan membuat kesimpulan sebagai bagian akhir dari proses pengolahan data. Teori dan model pembelajaran dari pendapat para ahli menjadi acuan bagi tenaga pendidik dalam menetapkan tujuan dan cara belajar yang akan dilaksanakan. Teori belajar merupakan dasar mengembangkan model yang akan digunakan. Model belajar menjadi ketentuan dalam menentukan langkah-langkah yang akan dilakukan dalam proses belajar yang akan dilaksanakan.
\end{abstract}

Kata Kunci: teori belajar, model pembelajaran

\section{Pendahuluan}

Keberhasilan proses pembelajaran tidak terlepas dari ketepatan tenaga pendidik dalam memilih dan menerapkan teori dan model belajar di dalam kelas. Peserta didik akan belajar dengan baik jika guru mampu merancang pembelajaran dengan baik. Menurut Ukti Lutvaidah (2015) menjelaskan bahwa dalam setiap mengikuti proses pembelajaran sudah pasti setiap peserta didik mengharapkan hasil belajar yang baik, sebab hasil belajar yang baik dapat membantu mereka dalam mencapai tujuannya. Hasil belajar yang baik hanya dicapai melalui proses belajar yang baik pula. Pembelajaran adalah suatu kegiatan yang bernilai edukatif, nilai tersebut mewarnai interaksi yang terjadi antara guru dan siswa. Interaksi dalam kegiatan pembelajaran dikatakan bernilai edukatif karena diarahkan untuk mencapai tujuan tertentu yang telah dirumuskan sebelum pembelajaran dilakukan, dengan harapan bagaimana materi pelajaran yang disampaikan dapat dikuasai dan dimengerti oleh siswa secara tuntas (Kartiani, 2015).

Model pembelajaran merupakan kerangka konseptual yang melukiskan prosedur yang sistematis dalam mengorganisasikan pengalaman belajar untuk mencapai tujuan belajar tertentu. Model pembelajaran berfungsi sebagai pedoman bagi para perancang pembelajaran dan para pengajar dalam merencanakan aktivitas belajar mengajar. Dengan demikian aktivitas pembelajaran benarbenar merupakan kegiatan bertujuan yang tertata secara sistematis. Sejalan dengan pendapat Joyce bahwa "Each model guides us as we design instruction to help student achieve various objectives". Maksud kutipan tersebut adalah bahwa setiap model mengarahkan kita dalam merancang pembelajaran untuk membantu peserta didik mencapai tujuan pembelajaran (Trianto, 2011). 
Makalah: disampaikan pada mata kuliah Pengembangan Model Pembelajar IPS. UPI, 2015.

\section{Metode}

Metode yang digunakan dalam tulisan ini adalah menggunakan pendekatan deskriptif kualitatif dengan jenis penelitian kepustakaan yaitu mengumpulkan data yang tertumpu pada penelaahan kritis dan mendalam terhadap bahan-bahan pustaka yang relevan (Nana Syaodih Sukmadinata, 2007 hal 60-61). Penggunaan bahan-bahan pustaka yang relevan dapat dilakukan melalui proses penyeleksian sumber relevan, melakukan refleksi, menganalisis, dan membuat kesimpulan sebagai bagian akhir dari proses pengolahan data.

\section{Hasil dan Pembahasan}

1. Model pembelajaran menurut Bruce Joyce, Marsh Weil dan Emily Calhoun (2009) dikelompokkan menjadi empat yaitu kelompok model yang memproses informasi, kelompok model pengajaran sosial, kelompok model pengajaran personal dan kelompok model sistem-sistem perilaku. Dan semua model pembelajaran tersebut memiliki unsurunsur berupa sintaks; sistem sosial; prinsip reaksi; sistem pendukung; dan dampak instruksional dan dampak pengiring. Karena unsur model berbeda dari satu dengan lainnya maka berikut ini dijelaskan berdasarkan contoh sebagai berikut;

(a). Yang termasuk ke dalam model pemrosesan informasi misalnya adalah model berpikir induktif. Struktur modelnya terdiri dari pembentukan konsep (mengkalkulasi dan membuat daftar, mengelompokan, membuat label dan kategori); interpretasi data (mengidentifikasi hubungan-hubungan yang penting, mengeksplorasi hubungan, membuat dugaan/kesimpulan); penerapan prinsip (memprediksi konsekuensi, menjelaskan fenomena asing, menghipotesis, menjelaskan dan atau mendukung prediksi dan hipotesis, menguji kebenaran); sistem sosial (model ini bersifat kooperatif dan guru tetap berperan sebagai inisiator dan pengawas semua kegiatan); peran/tugas guru (guru menyesuaikan tugas-tugas dengan tingkat aktivitas kognitif, menentukan kesiapan siswa); system pendukung (siswa membutuhkan data mentah untuk diolah/dianalisis); dampak instruksional dan pengiring (model ini dirancang untuk melatih siswa dalam membentuk konsep, model ini melatih siswa untuk focus pada logika, bahasa dan arti kata-kata dan sifat pengetahuan.

(b). model pengajaran sosial misalnya investigasi kelompok. Struktur pengajaran (menyajikan situasi yang rumit, menjelaskan dan menguaraikan reaksi terhadap situasi, merumuskan tugas, studi mandiri dan kelompok, menganalisis perkembangan dan proses, mendaur ulang aktivitas); sistem sosial berlandaskan proses demokrasi dan keputusan kelompok; peran/tugas guru, guru berperan sebagai fasilitator yang langsung terlibat dalam kelompok; sistem pendukung lingkungan harus mampu merespon tuntutan pembelajar.

(c). Yang termasuk dalam model pengajaran personal adalah pengajaran terarah. Struktur pengajaran (menjabarkan keadaan yang membutuhkan batuan, mengeksplorasi maslah, mengembangkan wawasan, merencanakan dan membuat keputusan, keterpaduan); sistem sosial (diskusi menjadi maslah inti); peran/tugas guru (guru menjangkau siswa, berempati, membantu menjelaskan masalah, bertindak untuk mencapai solusi); sistem pendukung (guru membutuhkan tempat yang tenang dan pusat sumber daya untuk berkonfrensi dan berdiskusi mengenai kontrak akademik).

Dan (d). yang termasuk dalam model sistem perilaku yaitu model simulasi. Struktur pengajaran (tahap orientasi, latihan partisipasi, pelaksanaan simulasi, wawancara 
partisipan), sistem sosial (guru mengarahkan simulasi, lingkungan kelas yang interaktif, penuh kerjasama), peran/tugas guru (guru memainkan peran suportif, yaitu mengamati dan memantau siswa dalam menghadapi masalah yang muncul), sistem pendukung (simulasi membutuhkan sumber daya material yang terstruktur).

2. Persamaan antara model pembelajaran Joyce dan Weil dengan Arthur L Costa

\begin{tabular}{|c|c|}
\hline Model Arthur L Costa & Model Joyce dan Weil \\
\hline $\begin{array}{l}\text { Directive strategies, yang digunakan oleh Arthur } \\
\mathrm{L} \text { Costa adalah untuk menekankan } \\
\text { pembelajaran dalam mencapaitujuan bahwa } \\
\text { siswa dapat meniru perilaku dan keterampilan } \\
\text { yang dimodelkan ataudiperagakan dan } \\
\text { diistruksikan oleh guru. strategi ini ditujukan } \\
\text { untuk membantu siswa dalam memperoleh dan } \\
\text { menerima fakta gagasan dan keterampilan. }\end{array}$ & $\begin{array}{l}\text { Model pemebelajaran sistem perilaku yaitu } \\
\text { fokus pada perilaku yang bisa diamati. } \\
\text { Pembelajaran instruksi langsung, belajar dari } \\
\text { simulasi, pembelajaran menguasai. }\end{array}$ \\
\hline $\begin{array}{l}\text { Meditative strategies, strategi ini ditujukan untuk } \\
\text { membantu siswa mengembangkan penalaran } \\
\text { konsep-konsep dan proses-proses pemecahan } \\
\text { masalah dan disebutkan yang termasuk dalam } \\
\text { strategi ini diantaranya adalah strategi induktif } \\
\text { dan latihan inkuiri. }\end{array}$ & $\begin{array}{l}\text { Kelompok model pemrosesan informasi } \\
\text { terdiri dari strategi belajar secara induktif, } \\
\text { pencapaian konsep-konsep, model induktif } \\
\text { kata bergambar, penelitian ilmiah dan latihan } \\
\text { penelitian, penghafalan, sinektik, dan belajar } \\
\text { dari presentasih. }\end{array}$ \\
\hline $\begin{array}{l}\text { Generative strategies, strategi ini ditujukan } \\
\text { untuk membantu siswa mengembangkan solusi } \\
\text { baru, kekuatan berpikir untuk memecahkan } \\
\text { masalah dan kreativitas. }\end{array}$ & $\begin{array}{l}\text { Kelompok model pembelajaran personal. } \\
\text { Pembelajar selalu belajar. Kepribadian mereka } \\
\text { adalah apa yang berinteraksi denganlingkungan } \\
\text { pembelajaran. }\end{array}$ \\
\hline $\begin{array}{l}\text { Collaborative strategies, strategi ini ditujukan } \\
\text { untuk membantu siswa belajar berhubungan } \\
\text { dengan orang lain dan kerja sama dengan } \\
\text { kelompok. Pembelajar ini merupakan strategi } \\
\text { pembelajaranyang mengembangkan hubungan } \\
\text { kerjasama dalam mengerjakan tugas-tugas } \\
\text { akademik didalam kelas. } \\
\text { (http://www.academia.edu/10138647/makalah_developing_mind.) }\end{array}$ & $\begin{array}{l}\text { Kelompok model pengajaran sosial. Model } \\
\text { ini mengembangkan apa yang dapat dilakukan } \\
\text { bersama-sama dan menciptakan suasana } \\
\text { akademis dalam masyarakat. } \\
\text { (Joyce, Weil dan Calhoun, 2009). }\end{array}$ \\
\hline
\end{tabular}

Berdasarkan persamaan tersebut di atas, maka dapat diidentifikasi pula perbedaannya yaitu bahwa model belajar yang dirumuskan oleh Joyce dan Weil tergambar secara rinci dalam arti bahwa model yang dimaksud adalah lebih bersipat umum dengan berbagai metode pembelajaran yang terdapat pada masing-masing model tersebut. Sedangkan pembelajaran yang diuraikan oleh Arthur L Costa lebih spesifik karena setiap strategi yang digunakan langsung focus pada langkah-langkah penerapan yang sipatnya lebih operasional.

3. Dari sudut pandang etologi, perilaku dipandang sebagai hasil interaksi antar keturunan dengan lingkungan, dan penekannya adalah pada pengaruh faktor etologi terhadap perilakuperilaku yang berbasis genetik. Artinya meskipun pembawaan genetik berperan sejak awal, faktor-faktor lingkungan dan tekanan selektif untuk berubah juga memberikan pengaruh yang penting. Menurut pandangan sosiobiologis beranggapan bahwa genetik menjadi hal yang terpentig dalam kaitannya dengan perilaku. Kebanyakan ahli sosiobiologis yakin 
Makalah: disampaikan pada mata kuliah Pengembangan Model Pembelajar IPS. UPI, 2015.

bahwa sifat altruism yaitu kemampuan manusia untuk mengorbankan dirinya untuk orang lain merupakan dasar genetik bukan dari pendidikan.

Sebagai kesimpulan dari kajian sosiobiologis adalah bahwa segala sesuatu yang dilakukan oleh binatang, entah perjuangan hidup melawan pemangsa, ataupun berkeliaran mencari makan, maka hal itu dilakukan dalam rangka untuk mencapai tujuan memproduksi diri. (Supardan, 2015: 152).

Salah satu tujuan memproduksi diri sebagaimana tersebut di atas adalah fungsi pengasuhan menjadi penting. David Brash mendefinisikan investasi orang tua sebagai perilaku tertentu orang tua yang meningkatkan kemungkinan kelangsungan hidup dan reproduksi anak tertentu dengan mengesampingkan investasi pada anak yang lainnya. Kemudian pemikiran tersebut dielaborasikan oleh Lionel Tiger dan Robin Fox yang menyatakan bahwa banyak bentuk perilaku berasal dari upaya-upaya individu untuk memaksimalkan kemampuan menyesuaikan diri inklusif mereka. (Supardan, 2015: 154). Kesimpulan dari teori kin selection adalah bahwa ikatan manusia didasarkan pada tingkat keterkaitan genetik. Oleh karena itu, semakin dekat ikatan kekeluargaan maka semakin besar signifikansi hubungan sosial yang dihasilkan.

Perlawanan keras terhadap konsep tersebut di atas datang dari Marshall Sahlins yang mengatakan bahwa kekeluargaan manusia diorganisasikan oleh kebudayaan yaitu dengan definisi-definisi social yang digunakan untuk mengidentifikasi siapa yang termasuk atau bukan keluarga dekat dan bukan ditentukan oleh alam yakni tingkat genetikal actual. Dengan kata lain kebudayaan dapat membuat keluarga yang jauh secara genetik menjadi keluarga dekat dan keluarga yang dekat secara genetik menjadi keluarga yang jauh. Secara umum Sahlins menyimpulkan bahwa keluarga manusia tidak diorganisasikan menurut keterkaitan genetic diantara para individu, tetapi merupakan kenyataan yang unik yang terbatas dari diterminasi hubungan-hubungan alamiah. (Supardan, 2015: 156).

4. Perbedaan dan persamaan teori belajar Bolles dengan teori belajar Bronfenbrenner yaitu:

Konsep teori belajar Bolles secara keseluruhan terdiri dari empat konsep yaitu ekspektasi, predisposiosi bawaan, motivasi membatasi fleksibilitas respons, dan argument tempat. Dalam teori belajar Bolles lebih menekankan pada peran S-S dan R-S dalam belajar. Misalnya ekspektasi (pengharapan) yakni organisme belajar satu jenis kejadian yang mendahului kejadian lainnya. Bolles menjelaskan penggondisian klasik sebagai ekspektasi yang dipelajarai yang ketika diberi dengan satu stimulus (CS) akan menimbulkan stimulus lainnya (US). Secara umum urutan temporal dan kontiguitas temporal antara dua stimuli atau antar respons dan konsekuensinya akan menentukan sifat dari ekspektasi yang dipelajari. Misalnya kilat akan menjadi prediktor akan munculnya petir. Pada konsep predisposisi bawaan, Bolles menekankan pada ekspektasi S-S dan R-S bawaan dalam analisisnya terhadap perilaku. Misalnya S-S bawaan, ketika bayi menunjukkan ketakutan akan suara keras, mengisyaratkan bahwa bayi tersebut memperkirakan peristiwa bahaya yang diikuti. Sedangkan contoh R-S bawaan adalah terjadinya perilaku streotip yang banyak dilakukan spesies saat menghadapi makanan, bahaya, dan objek atau kejadian biologis lainnya. Pada konsep motivasi membatasi fleksibilitas respons, Bolles menjelaskan bahwa motivasi dan belajar tidak dapat dipisahkan, akan tetapi seseorang harus tahu baik itu keadaan motivasional maupun apa yang secara alamiah dilakukan organisme tersebut dalam keadaan motivasional itu. Dan pada konsep argument tempat, Bolles mengatakan bahwa tempat sangat mempengaruhi bentuk-bentuk belajar yang organisme lakukan dimana 
Makalah: disampaikan pada mata kuliah Pengembangan Model Pembelajar IPS. UPI, 2015.

menurutnya bahwa organism memiliki kewajiban untuk belajar atau tidak tergantung pada tempat mereka berada dan bagaimana mereka menyesuaikan diri dengan keseluruhan skema. (Hergenhan dan Olson,2009: 446-448 \& Supardan, 2015: 146).

Sedangkan konsep teori belajar dari Urie Bronfenbrenner lebih difokuskan pada pengaruh konteks sosial dimana anak itu tinggal dan orang-orang yang mempengaruhi perkembangan anak tersebut. Teori ini terdiri dari lima sistem lingkungan yang merentang dari interaksi interpersonal sampai pada pengaruh kultur yang lebih luas yaitu mikrosistem, mesosistem, ekosistem, makrosistem, dan kronosistem. Dalam teori belajar Urie Bronfenbrenner ini dijelaskan bahwa banyaknya konteks sosial yang berinteraksi dalam sistem lingkungan baik keluarga, teman sebaya, sekolah, tetangga, (sebagai sistem lingkungan yang mikro); hubungan antar sekolah dengan keluarga (sebagai mesosistem); dewan sekolah, dewan pengawas taman, fasilitas rekreasi, dan perpustakaan (sebagai ekosistem); nilai dan adat istiadat masyarakat (sebagai makrosistem); dan keadaan ekonomi suatu masyarakat (sebagai kronosistem) sangat mempengaruhi kualitas dan perkembangan dengan model bioekologis. (Supardan, 2015: 278).

Kedua konsep teori belajar tersebut juga sama-sama menekankan pada pentingnya perlan lingkungan atau tempat terhadap perkembangan perilaku organism. Dimana dalam konsep Bolles organisme dapat belajar atau tidak sangat tergantung pada tempat dimana organism itu berada. Sedangkan dalam konsep Bronfenbrenner bahwa perkembangan organism itu sangat ditentukan oleh banyaknya interaksi sosial yang terjadi dan dialami oleh organisme baik pada sistem lingkungan yang mikro, meso, ekosistem, makro dan kronosistem. Artinya interaksi dalam sistem lingkungan baik keluarga, teman sebaya, sekolah, tetangga; hubungan antar sekolah dengan keluarga; dewan sekolah, dewan pengawas taman, fasilitas rekreasi, dan perpustakaan; sistem nilai dan adat istiadat masyarakat; dan keadaan ekonomi suatu masyarakat sangat mempengaruhi kualitas dan memainkan peran yang positif dalam perkembangan organisme.

5. Perbedaan dan Persamaan teori belajar refleksiologi Watson, dengan teori belajar koneksionisme Thorndike, dan teori belajar kondisioning operan Skinner adalah:

Watson adalah seorang yang mendukung peran lingkungan terhadap karakter seseorang. Teori belajar Watson bersandar pada dua prinsip yaitu prekuensi dan resensi. Prinsip prekuensi menyatakan bahwa semakin sering kita melakukan suatu respon terhadap stimulus tertentu, semakin cenderung kita menjadikan respon tersebut sebagai stimulus lagi. Begitu pula halnya dengan prinsip resensi yaitu semakin baru atau kekinian kita melakukan respon terhadap stimulus tertentu, semakin cenderung kita melakukannya lagi. Dengan demikian maka teori belajar ini lebih mementingkan proses pengualangan dan proses memberikan respon terhadap suatu stimulus harus dilakukan dengan segera. Watson kurang mendukung pada faktor penguatan (reinforcement), imbalan (reward), dan hukuman (punishment) sebagai penyebab terjadinya pembelajaran. Watson berpandangan bahwa apa yang dapat membuat kita dapat belajar stimulus respon adalah semata-mata karena keduanya berlangsung beriringan. Artinya bahwa pembelajaran dapat dihasilkan melalui keberiringan belaka, tanpa penguatan. Pemikiran Watson tentang karakteristik hubungan stimulus respons yakni bergantung pada prinsip prekuensi atau latihan dan prinsip kekinian. (Supardan, 2015: 248).

Teori belajar Thorndike menyatakan bahwa bentuk paling dasar dari proses belajar adalah trial and error learning atau yang disebut sebagai selecting and connecting. Thorndike menyimpulkan bahwa belajar bersifat bertahap, bukan langsung ke penguasaan 
Makalah: disampaikan pada mata kuliah Pengembangan Model Pembelajar IPS. UPI, 2015.

substansi. Belajar adalah bersifat langsung dan tidak dimediasi oleh pemikiran dan penalaran. Bahwa mamalia termasuk manusia belajar dengan cara yang sama. Dalam teori Thorndike dikenal istilah hukum kesiapan, hukum latihan, hukum efek, hukum belongingness, dan konsep penyebaran efek. Dalam teori ini mengutamakan reward, reinfoecement, dan punishing yang digunakan pada hukum kesiapan. (Hergenhan dan Olson, 2009: 60; Schunk, 2012: 103; Supardan, 2015: 238).

Teori belajar Skinner lebih menekankan pada perilaku yang perlu dicermati yakni respondent behavior (perilaku responden) yang ditimbulkan oleh suatu stimulus yang dikenal, dan perilaku operant behavior (perilaku operan) yang tidak diakibatkan oleh stimulus yang dikenal, tetapi dilakukan sendiri oleh organisme. Pengkondisian tipe $S$ yang dinamakan respondent conditioning (pengkondisian responden) lebih menekankan arti pentingnya stimulus. Sedangkan pengkondisian tipe $\mathrm{R}$ yang dinamakan operant conditioning lebih menekankan pada respons. Prinsip umum dari pengkondisian tipe $\mathrm{R}$ adalah bahwa setiap respons yang diikuti dengan stimulus yang menguatkan cenderung akan diulangi, dan stimulus yang menguatkan adalah segala sesuatu yang memperbesar rata-rata terjadinya respons operan, atau sebuah penguat adalah segala sesuatu yang meningkatkan probabilitas terjadinya kembali suatu respons. (Hergenhan dan Olson, 2009: 85; Supardan, 2015: 252).

Ketiga tokoh baik Watson, Thorndike, dan Skinner adalah sama-sama mengusung teori belajar yang mengedepankan stimulus dan respons. Disamping itu proses pengulangan dan latihan merupakan konsep persamaan yang terdapat dalam teori belajar ini. Artinya dalam teori belajar menurut pemikiran Watson tentang karakteristik hubungan stimulus respons yakni bergantung pada prinsip prekuensi atau latihan dan prinsip kekinian. Dalam teori belajar Thorndike dikenal dengan hukum kesiapan dan latihan. Sedangkan prinsip umum dari pengkondisian tipe $\mathrm{R}$ dari teori belajar Skinner adalah bahwa setiap respons yang diikuti dengan stimulus yang menguatkan cenderung akan diulangi, dan stimulus yang menguatkan adalah segala sesuatu yang memperbesar rata-rata terjadinya respons operan, atau sebuah penguat adalah segala sesuatu yang meningkatkan probabilitas terjadinya kembali suatu respons. Dengan demikian proses pengulangan dan latihan merupakan titik persinggungan dari ketiga teori ini.

\section{Teori Belajar Atribusi dari Bernard Weiner.}

Istilah atribusi mengacu pada penyebab sesuatu kejadian, atau hasil menurut persepsi individu. Fokus utama dari teori ini adalah penggolongan penyebab tingkah laku menurut persepsi; hukum umum yang menghubungkan informasi anteseden dengan struktur kognitif seseorang; dan perkembangan persambungan antara infrensi penyebab dengan tingkah laku yang nampak muncul berikutnya. Dalam teori ini, terdapat peristiwa internal yang bertindak sebagai perantara stimulus tugas dan tingkah laku individu berikutnya. Orang yang motivasi berprestasinya tinggi cenderung melihat dirinya lebih mampu dari orang lain dan cenderung lebih banyak melakukan tugas-tugas untuk prestasi tersebut. (Weiner dalam Supardan, 2015: $50)$.

Faktor penyebab dicapainya keberhasilan maupun kegagalan serta dalam hubungan dengan tingkah laku berikutnya yaitu, kemampuan; usaha; kesulitan tugas; dan kemujuran. Asumsi dasar teori atribusi adalah bahwa mencari pemahaman itu sumber utama dari motivasi manusia. Pencarian informasi dan usaha untuk memeriksa kebenaran sesuatu dapat dijadikan sebagai motivator utama yang berpengaruh terhadap tingkah laku. Disamping itu, tingkah laku di waktu yang akan datang sangat dipengaruhi oleh sistem kepercayaan dan analisis kognitifnya mengenai sebab-sebab diperolehnya hasil yang positif atau negatif. 
Dengan demikian, tiga asumsi dasar dari teori ini adalah usaha mencari pemahaman sebagai motivator utama bagi suatu tindakan; atribusi merupakan sumber yang komplek dari informasi mengenai hasil tindakan; dan tingkah laku yang akan datang ditentukan sebagian oleh persepsi sebab-sebab hasil tindakan sebelumnya. (Supardan, 2015: 50).

Teori atribusi berkaitan dengan bagaimana individu menginterpretasikan peristiwa dan bagaimana ini berhubungan dengan perilaku dan pemikiran mereka. Teori atribusi berasumsi bahwa orang-orang mencoba untuk menentukan mengapa orang-orang melakukan apa yang mereka kerjakan yakni menghubungkan penyebab dengan tingkah laku. Tiga proses tahapan yang mendasari suatu atribusi yaitu orang/individu harus merasakan atau mengamati perilaku itu; orang/pribadi harus percaya bahwa perilaku itu dengan sengaja dilakukan; dan orang harus menentukan jika mereka percaya terhadap orang lain terpaksa melakukan perilaku itu dalam hal mana penyebab adalah melekat pada situasi itu atau bukan. (Supardan, 2015: 52).

Berdasarkan inti dari konsep teori belajar atribusi Weiner adalah bukan sekedar sebuah penilaian terhadap proses penyebab keberhasilan dan kegagalan yang dialami oleh seseorang, akan tetapi lebih kepada proses menyiapkan perilaku atau usaha apa yang seharusnya dilakukan oleh seseorang di masa yang akan datang berdasarkan pengalaman atau hasil yang diperoleh pada saat ini. Artinya bahwa baik keberhasilan maupun kegagalan yang diperoleh harus dijadikan sebagai atribusi untuk tindakan yang lebih baik yang seharusnya dipersiapkan di masa yang akan datang. Dalam hal ini kemungkinan akan muncul dua tipe individu yaitu individu dengan tipe motivasi berprestasi tinggi dengan individu dengan tipe motivasi berprestasi rendah. Bagi mereka yang motivasi berprestasinya tinggi maka lebih cenderung menyalahkan diri sendiri untuk melakukan refleksi terhadap proses yang dipersiapkan dan hasil yang diperoleh saat ini dijadikan sebagai motivasi untuk perbaikan pada hari berikutnya. Sedangkan bagi mereka yang memiliki motivasi berprestasi rendah akan lebih cenderung menyalahkan orang lain.

Contohnya: jika sekelompok siswa yang diberikan tes matematika, maka jika dari hasil tes tersebut terdapat beberapa siswa yang mengalami kegagalan. Dan kegagalan itu dikarena prekuensi dalam mempelajari materi yang masih minim disamping terdapat kesalahan dalam menafsirkan maksud soal yang telah diberikan. Sehingga para siswa diberikan tugas untuk mengerjakan soal latihan matematika untuk mengasah kemampuan mereka. Bagi sebagian siswa yang tergolong bermotivasi tinggi tentu tidak akan menghindari tugas yang diberikan, akan tetapi lebih cenderung untuk lebih teliti dalam mencermati soal yang akan dikerjakan. Sedangkan bagi sebagian yang memiliki motivasi berprestasi rendah akan tetap beranggapan bahwa soalnya sangat sulit, soalnya tidak persis sama dengan contoh yang diberikan dan lain-lain alasan yang membuat mereka akan tetap gagal dalam mengerjakan soal tersebut.

Kritik dari ahli lain misalnya Graham dan Barker (1990:2) menjelaskan bahwa kegagalan seseorang bukanlah untuk dikasihani atau diberi belas kasihan, karena jika terjadi demikian maka motivasi berprestasi siswa tidak akan terbangun dalam diri mereka. Mereka tidak akan mungkin melakukan refleksi terhadap kegagalan yang telah dihadapi apalagi harus menemukan solusi dari keggagalan tersebut. Dengan demikian, kesuksesan seseorang karena faktor bantuan dari orang lain yang dilakukan secara sengaja maka akan cenderung dipersepsikan oleh orang lainnya bahwa orang tersebut memiliki kemampuan yang rendah. Akan tetapi menurut pendapat penulis pola tersebut jika terjadi pada siswa yang bermotivasi tinggi boleh jadi akan menimbulkan kepercayaan diri sehingga berusaha untuk menghindari 
Makalah: disampaikan pada mata kuliah Pengembangan Model Pembelajar IPS. UPI, 2015.

bantuan yang diberikan. Dan jika terjadi pada siswa yang bermotivasi rendah maka pola ketergantungan akan muncul untuk selalu mengharapkan datangnya bantuan setiap kali mereka mengalami kegagalan sehingga tetap saja tidak dapat meningkatkan motivasi berprestasi mereka.

\section{Teori Fenomenografi}

Dari sudut kajian fenomenografi, hasil pembelajaran merupakan komponen pembelajaran yang sama pentingnya dengan proses pembelajaran. Kedua aspek ini amat berhubungan erat dan pemahaman tentangnya akan dapat membantu pendidik kearah meningkatkan mutu pembelajaran (Marton dalam Supardan, 2015: 25). Penyelidikan fenomenografi lebih bertujuan untuk mengkaji tentang apakah yang difahami atau dipelajari oleh pembelajar tentang isi atau keduanya itu lebih merupakan sesuatu pelajaran yang menekankan fakta kuantitatif pelajaran atau sebaliknya.

This conceptual framework focuses on the experience of learning from the student's perspective and is based upon a phenomenological approach to research. Entwistle explains: "Our task is thus to describe more clearly how learning takes place in higher education and to point out how teaching and assessment affect the quality of learning. From these descriptions teachers should be able to draw their own lessons about how to facilitate their students' learning" (Marton, Hounsell \& Entwistle, 1984, p.l dalam http//Instructional Design Models).

Menurut Marton dan Saljo (Supardan, 2015: 25), jika pembelajar menerapkan pendekatan pembelajaran tersebut dengan hasrat untuk memahami isi kandungannya, maka peluang untuk dia memahami teks tersebut serta menguasai fakta-fakta penting adalah besar peluangnya. Tetapi, jika seseorang pembelajar itu memusatkan perhatiannya kepada penguasaan mengingat fakta-fakta dan memperlakukan penugasan yang diberikan sebagai suatu yang membebankan, maka tingkat pemahaman terhadap materi pembelajaran yang dihasilkan adalah lemah. Hal ini bermakna, bahwa pembelajar yang salah menafsirkan dan hanya berusaha mengingat kembali fakta-fakta yang diterimanya, bukan semata-mata disebabkan oleh kurangnya usaha atau kerja keras. Semuanya itu berpusat dari niat atau tujuan belajar yang tertanamkan di hati mereka sendiri.

Pendapat di atas didukung ini didukung oleh Van Rossum dan Schenk (1984) dan Wan Ali (1993) bahwa tujuan kajian fenomenologi ini ialah menelaah perbedaan kualitatif yang terdapat dalam jawaban pembelajar terhadap suatu masalah. Di samping meneliti aspek tingkat pemahaman, penyelidikan ini juga bertujuan untuk meneliti corak jawaban yang ditunjukkan oleh pembelajar. (Supardan, 2015: 26).

Motivasi awal penelitian fenomenografi adalah untuk meneliti bagaimana pembelajar memandang dan memahami dunia akademik yang mereka alami. Untuk ini, penelitian fenomenografi biasanya dilakukan dengan cara meminta pembelajar melakukan suatu kegiatan akademik (membaca teks ilmiah, misalnya) dan kemudian menanyakan (melalui wawancara kualitatif) makna kegiatan tersebut bagi mereka. Selanjutnya transkrip wawancara dan hasil observasi atas proses belajar inilah yang menjadi data utama penelitian fenomenografi (Bowden dalam Supardan, 2015: 26).

Salah satu temuan utama fenomenografi adalah bahwa ada dua cara yang berbeda yang diambil oleh pembelajar ketika melakukan kegiatan akademik. Dua cara ini kemudian dikenal dengan istilah pendekatan belajar dangkal (surface learning) dan belajar mendalam (deep learning) (Biggs, 2003; Marton \& Saljo, 2005 dalam Supardan, 2015: 27). 
Makalah: disampaikan pada mata kuliah Pengembangan Model Pembelajar IPS. UPI, 2015.

\section{Penerapan dalam pembelajaran.}

Jika kita ingin mengetahui apakan siswa atau mahasiswa itu selama ini ia melakukan proses belajar secara dangkal atau melakukan proses belajar secara mendalam, maka dapat dilakukan melalui pemberian tugas kepada mereka untuk dianalisis. Misalnya mahasiswa diberikan tugas untuk melakukan kritikal review tentang sebuah artikel, maka di bawah artikel tersebut harus disertakan dengan beberapa pertanyaan yang bervariasi mulai dari pertanyaan sederhana tentang apa konsep, tema dan sub tema dari artikel tersebut, sampai dengan bagaimana posisi dan pandangan penulis terhadap persoalan yang diangkat dalam artikel tersebut. Berdasarkan pertanyaan yang sudah dimuat pada akhir dari artikel tersebut, maka dapat diidentifikasikan dari jawaban mahasiswa kelompok-kelompok yang belajar secara dangkal dan kelompok-kelompok mahasiswa yang belajar secara mendalam. Jika dari hasil analisis jawaban yang diberikan lebih dominan pada pengungkapan fakta-fakta dari apa yang terdapat dalam artikel tersebut, maka mereka tergolong ke dalam belajar secara dangkal. Jika mereka menganalisis lebih jauh dari sekedar fakta, misalnya lebih mengarag pada makna secara kualitatif dari apa yang dianalisisnya dari artikel tersebut maka mereka tergolong ke dalam belajar secara mendalam.

\section{Kontribusi dan kritiknya.}

Teori fenomenografi memberikan kontribusi yang sangat besar dalam upaya mengidentifikasi pola belajar siswa/mahasiswa dan selanjutnya dapat dilakukan perbaikan terhadap pola belajar tersebut dengan melatih kemampuan analisis siswa/mahasiswa terhadap suatu permasalahan yang dihadapi. Hasil pembelajaran berupa pemahaman terhadap makna dari isi pembelajaran adalah sama pentingnya dengan proses pembelajaran itu sendiri. Dengan demikian, hasil belajar yang dangkal perlu dilakukan proses yang mengarahkan pada pola yang lebih mendalam terhadap cara belajar yang dilakukan. Begitu pula dengan hasil belajar yang mendalam perlu terus dilatih agar kemampuan belajar analisis secara mendalam dapat menjadi komponen yang melekat pada diri siswa atau mahasiswa. Menurut hemat penulis bahwa teori fenomenografi sangatlah penting dipahami oleh guru di sekolah agar secara dini dapat membentuk pola belajar siswa yang lebih mengarah pada pola belajar secara mendalam sehingga kemampuan berfikirnya dapat terlatih dengan baik. Selama ini konsep belajar yang dilakukan terutama di tingkat sekolah dasar seolah-olah bahwa proses belajar secara mendalam belum layak diterapkan, sehingga lebih pada proses mengingat fakta-fakta dan konsep dari materi yang diajarkan. Padahal menurut hemat penulis, proses belajar secara mendalam itu perlu diterapkan sejak dini dalam tarap yang sesuai dengan perkembangan kognitif dan psikologis anak. Dengan terbiasanya proses berpikir analitik siswa maka pola ini akan melekat sebagai bagian dari gaya dirinya dalam melakukan proses belajar.

\section{Teori belajar metakognisi Flavel.}

Menurut Flavel, jika seseorang mengalami masalah dalam belajar, kemudian dia melakukan proses perbaikan secara sengaja terhadap cara belajarnya, maka definisi ini menunjukkan bahwa metakognisi dikaitkan dengan usaha yang sengaja dan sadar kearah perbaikan hasil pemikiran yang dilakukan. Selanjutnya Flavel mengemukakan model metakognisi yang lebih menekankan pada proses pemantauan kognitif yang disebutnya sebagai model of cognitive monitoring. Pemantauan terhadap berbagai hal ikhwal kognitif berlaku melalui tindakan dan interaksi antara empat kelas fenomena yakni pengetahuan metakognitif; pengalaman metakognitif/regulasi; tugas-tugas pengetahuan/kognitif; dan tindakan/strategi. (Supardan, 2015: 102). 
Pengetahuan metakognitif adalah pengetahuan tentang kognisi secara umum dan kesadaran akan pengetahuan tentang kognisi diri sendiri. Salah satu ciri belajarnya lebih menekankan pada metode untuk membuat siswa makin menyadari dan bertanggung jawab terhadap pengetahuan dan pemikiran mereka sendiri. (Supardan, 2015: 103).

Selanjutnya Falavel (Supardan, 2015: 103) menyatakan bahwa metakognisi meliputi pengetahuan tentang strategi, tugas, dan variabel-variabel person. Dalam kategori-kategori pada paradigm ini memasukkan pengetahuan siswa tentang strategi-strategi belajar dan berpikir, dan pengetahuan siswa tentang tugas-tugas, kapan dan mengapa harus menggunakan beragam strategi tersebut. Selain itu juga mencantumkan pengetahuan tentang diri dalam kaitannya dengan komponen-komponen kognitif dan motivasional dari performa.

Rencana pengembangan model pembelajaran metakognisi Flavel.

Penngembangan model pembelajaran metakognisi Flavel dapat dilakukan dengan mengacu pada tiga komponen metakognitif yang dijelaskan sebagaimana tersebut di atas yang menyatakan bahwa metakognisi meliputi pengetahuan tentang strategi, tugas, dan variabel-variabel person. Dalam kategori-kategori pada paradigm ini memasukkan pengetahuan siswa tentang strategi-strategi belajar dan berpikir, dan pengetahuan siswa tentang tugas-tugas, kapan dan mengapa harus menggunakan beragam strategi tersebut. Selain itu juga mencantumkan pengetahuan tentang diri dalam kaitannya dengan komponen-komponen kognitif dan motivasional dari performa.

Berdasarkan pada tiga komponen tersebut di atas yaitu

1. Pengetahuan strategi adalah perihal strategi-strategi belajar dan berpikir serta pemecahan masalah. Strategi dalam sub-jenis pengetahuan ini dapat digunakan dalam banyak tugas mata pelajaran, bukan hanya cocok untuk tugas tertentu dalam mata pelajaran tertentu. Misalnya strategi mengulang-ulang, strategi elaborasi dan strategi mengorganisasikan. Siswa yang mempunyai pengetahuan strategis dpat dikatakan memiliki cara-cara belajar tersebut serta mengetahui berbagai cara metakognitif yang dapat dimanfaatkan untuk merencanakan, memonitor dan mengatur kognisinya.

2. Pengetahuan tugas-tugas kognitif kontekstual dan kondisional yaitu yang mencakup pengetahuan berbagai tugas kognitif misalnya tugas untuk mengingat kembali. Pengetahuan tentang strategi-strategi belajar dan berpikir merupakan pengetahuan tentang apa manfaat strategi-strategi tersebut dan bagaimana menggunakan cara-cara itu. Sedangkan pengetahuan kondisional adalah bahwa siswa harus mengetahuai kapan dan mengapa menggunakan strategi-strategi tersebut dengan tepat. Dalam menerapkan pengetahuan kondisional juga harus memperhatikan norma-norma lokal situasional, sosial secara umum, konvensional, dan kultural.

3. Pengetahuan diri yaitu pengetahuan yang mencakup kekuatan dan kelemahan diri sendiri dalam kaitannya dengan kognisi dan belajar. Pengetahuan diri mencirikan seseorang yang ahli, bahwa dia tahu ketika dia tidak mengetahui sesuatu dan kemudian dia mempunyai strategi-strategi tertentu untuk mencari informasi yang dia butuhkan. Kesadaran diri akan keluasan dan kedalaman pengetahuan diri sendiri, menjadi aspek penting dalam pengetahuan diri. (Supardan, 2015: 102-106).

Mengacu pada tiga pengetahuan dalam metakognisi, maka model pembelajaran yang dapat dilakukan sesuai dengan pengetahuan tersebut adalah dapat dilihat dalam pola pengembangan sebagai berikut: 
I

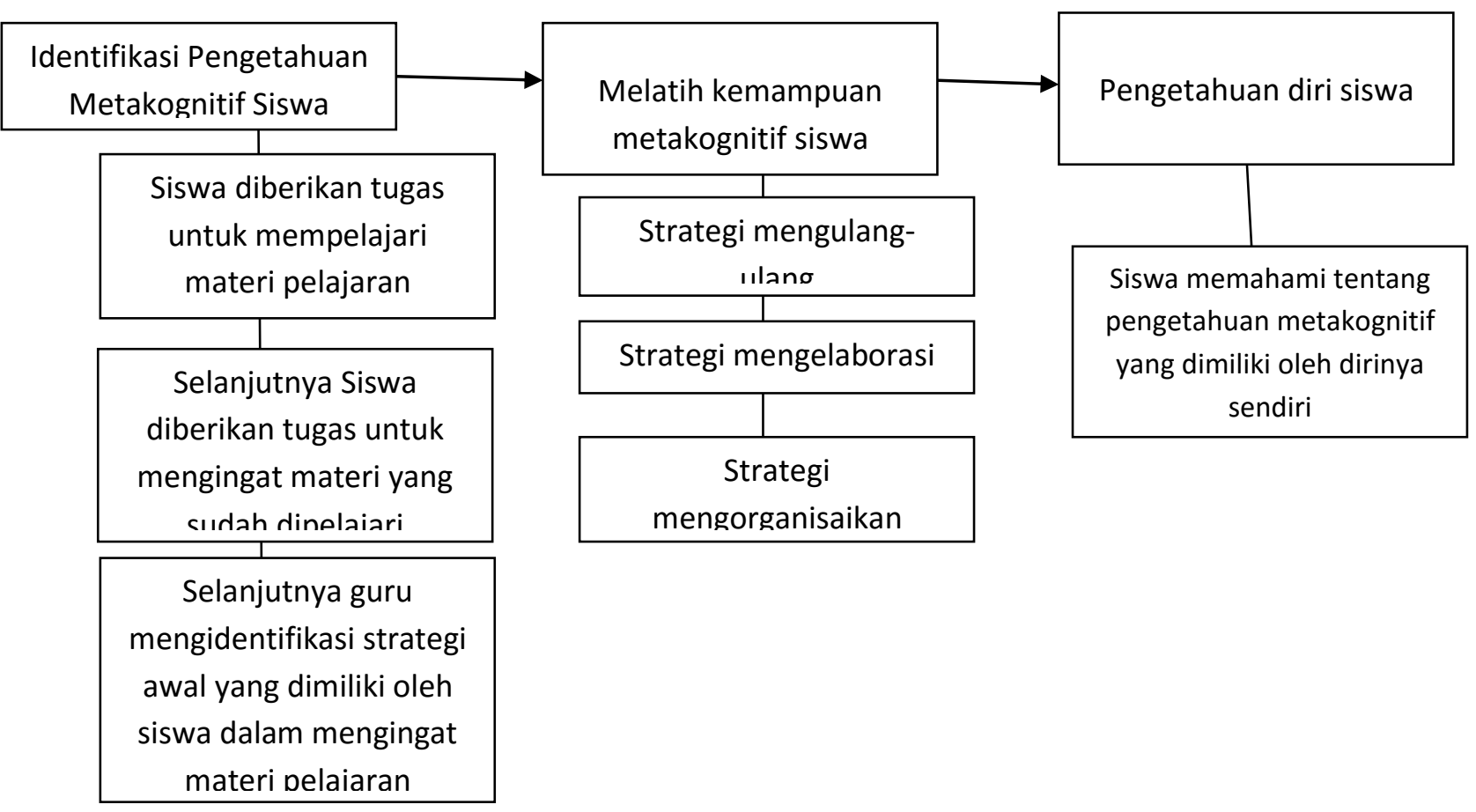

\section{Perbedaan dan Persamaan Teori belajar Abraham Maslow dengan Teori Belajar Carl Roger.}

Persamaan dari kedua teori ini adalah bahwa kedua-duanya memandang bahwa manusia itu baik atau sehat. Dengan kata lain mereka memandang kesehatan mental sebagai proses perkembangan hidup alamiah, sementara penyakit jiwa, kejahatan, dan persoalan kemiskinan lain dipandang sebagai penyimpangan dari kecenderungan alamiah. Roger didasarkan pada kecenderungan aktualisasi. Kecenderungan aktualisasi tersebut diartikan sebagai motivasi yang menyatu dalam setiap diri mahluk hidup dan bertujuan mengembangkan seluruh potensinya semaksimal mungkin. Hal ini terbukti dengan tingginya rasa ingin tahu anak apabila diberi kesempatan untuk mengeksplorasi lingkungan. (Supardan, 2015: 229). Sejalan dengan itu, Maslow menyatakan bahwa dalam setiap bayi yang lahir, terdapat kemampuan yang aktif ke ara kesehatan, impuls kearah pertumbuhan atau kea rah aktualisasi potensi-potensi manusia. Orang-orang sesungguhnya memiliki kodrat bawaan yang pada hakekatnya adalah baik atau sekurang-kurangnya netral. (Supardan, 2015: 219).

Sementara itu, letak perbedaannya adalah bahwa aktualisasi diri yang dimaksudkan oleh Roger merupakan motivasi yang melekat pada diri setiap individu dan bertujuan mengembangkan seluruh potensinya secara maksimal. Asumsi teori Roger yaitu kecenderungan formatif bahwa segala sesuatu di dunia ini tersusun dari hal-hal yang kecil dan kecenderungan aktualisasi bahwa semua mahluk hidup memiliki kecenderungan untuk bergerak menuju ke kesempurnaan atau pemenuhan potensi dirinya. (Supardan, 2015: 229).

Sedangkan Maslow telah membuat teori tentang motivasi manusia yang membedakan antara kebutuhan-kebutuhan dasar dan metakebutuhan-metakebutuhan yang semuanya tersusun secara hirarki dari kebutuhan fsiologi, keamanan, kebersamaan, keyakinan, dan aktualisasi diri. Kebutuhan dasar harus terpenuhi terlebih dahulu secara cukup sebelum kebutuhan-kebutuhan lainnya. Ketika kebutuhan dasar terpenuhi maka 
Makalah: disampaikan pada mata kuliah Pengembangan Model Pembelajar IPS. UPI, 2015.

setiap orang akan berusaha untuk memaksimalkan kebutuhan aktualisasi diri yaitu sebagai aktualisasi potensi, kapasitas, dan bakat yang sedang berlangsung. Manifestasi proses aktualisasi diri, pada hakikatnya merupakan rangkaian aktivitas motivasi yang kuat dalam upaya peraihannya. Pada hakekatnya, hirarki Maslow merupakan bimbingan umum yang berguna untuk memahami perilaku. Sebagai contoh, tidaklah realistis mengharapkan siswa belajar dengan baik di sekolah, jika mereka menghadapi kesulitan fisiologis dan defisiensi keamanan apalagi fisiologi kekurangan makanan. (Hall \& Lindzey, 1993: 109; Supardan, 2015: 218).

Pada tataran penerapannya dalam pembelajaran Maslow lebih menekankan bahwa proses pembelajaran akan berlangsung dengan baik jika siswa belajar dalam lingkungan belajar yang aman. Artinya bahwa belajar akan berlangsung dengan maksimal jika situasi dan kondisi berada dalam keadaan yang kondusif. Sedangkan Roger memandang bahwa yang terpenting dalam proses pembelajaran adalah pentingnya guru memperhatikan prinsip pendidikan dan pembelajaran yaitu menjadi manusia berarti memiliki kekuatan yang wajar untuk belajar, siswa mempelajari hal-hal yang bermakna untuk dirinya sendiri, Bahan pembelajaran yang diorganisasikan harus bahan dan ide baru sebagai bagian yang bermakna bagi siswa, dan belajar yang bermakna adalah belajar tentang proses.

Sementara itu kritikan teori humanistik Maslow dikatakan bahwa gerakan psikologi humanistik adalah suatu gerakan yang ngawur yang lemah karena tersusun dari jalinanjalinan yang terlalu banyak, terlalu berjauhan, dan kadang-kadang berlawanan sehingga tidak sanggup menghasilkan tindakan sama dan dalam waktu yang lama. Sedangkan pada teori Roger dipandang bahwa memang klien tidak memiliki seluruh sumber daya untuk dapat mencapai resolusi atas masalah moral atau pribadinya. Selanjutnya kesabaran guru atau terpisi membutuhkan kecenderungan etis yang sangat kuat dalam membantu subjek mengembangkan keterampilannya untuk refleksi dan revisi untuk menentukan nilai mereka dalam situasi tersebut.

\section{Perbedaan dan Persamaan Teori belajar Bandura dengan Martin dalam Pengembangan Pembelajaran yaitu:}

Bandura mengembangkan sudut pandang teoretis baru dimana individu dipandang sebagai perantara aktif yang bertindak terhadap lingkungan menurut harapan tertentu, tetapi individu juga berpegang pada wawasan atau pengetahuan mengenai apa kiranya yang akan menjadi konsekuensi dari perilakunya. Unsur penting lainnya dari teori belajar Bandura adalah asumsi bahwa pembelajaran pada hakikatnya berlangsung melalui peniruan atau pemodelan. Dalam teori belajar observasional ini peniruan jauh lebih kompleks karena individu dipahami sebagai pihak yang memainkan peran aktif dalam menentukan kelompok perilaku mana yang hendak ia tiru dan juga frekuensi serta intensitas peniruan yang hendak dijalankan. (Bandura dalam Supardan, 2015: 264). Sedangkan teori belajar Martin yang mengusulkan cita-cita pendidikan yang peka gender, yang menuntut pendidik untuk tetap menyadari pengaruh gender dalam kehidupan laki-laki dan perempuan dimana gender tidak membuat dan menciptakan perbedaan. (Supardan, 2015: 305).

Sedangkan persamaan kedua teori ini tergambar dari pentingnya peran lingkungan dalam belajar. Menurut Bandura, orang, lingkungan dan perilaku orang semuanya berinteraksi untuk menghasilkan perilaku selanjutnya. Ketiga komponen ini menurut Bndura saling mempengaruhi yaitu bahwa perilaku mempengaruhi lingkungan dan orang, atau lingkungan atau orang mempengaruhi perilaku. Dengan demikian menurut Bndura, orang dapat mempengaruhi lingkungan dengan bertindak dalam tata cara tertentu dan 
Makalah: disampaikan pada mata kuliah Pengembangan Model Pembelajar IPS. UPI, 2015.

perubahan lingkungan itu pada gilirannya akan mempengaruhi perilaku orang itu selanjutnya. (Supardan, 2015: 267). Selanjutnya Martin melakukan konseptualisasi ulang terhadap sekolah sebagai ekuivalen moral dari rumah, baik dalam belajar untuk hidup serta mempelajari kebudayaan yang didominasi atau yang mendominasi. Menurut Martin, lembaga bukan saja di rumah dan sekolah, melainkan juga tempat ibadah, pemukiman, tempat kerja, museum, perpustakaan, gedung tempat pertunjukan, media cetak dan elektronik. (Supardan, 2015: 306). Dengan demikian maka dapat disimpulkan bahwa dalam proses pengembangan model pembelajaran baik pada teori Bandura maupun pada teori Martin sama-sama mengedepankan unsur lingkungan sebagai salah satu komponen penting dalam pendidikan dan pembelajaran.

\section{Daftar Pustaka:}

Hall. C. S dan Lindzey G. 1993. Psikologi Kepribadian. Teori-Teori Holistik (OrganismikFenomenologis). Yogyakarta: Kanisius.

Hergenhahn. B. R. dan Olson. M. H. 2009. Theories of Learning (Teori Belajar) Edisi Ketujuh. Jakarta: Prenada Media Grup.

Joyce. B, Weil. M dan Calhoun. E. 2009. Models of Teaching. Model-Model Pembelajaran Edisi Kedelapan. Yogyakarta: Pustaka Pelajar.

Pengaruh Metode Pembelajaran dan Motivasi Belajar Terhadap Hasil Belajar Siswa Pada Mata Pelajaran IPS Kelas V Kabupaten Lombok Barat NTB. Jurnal Pendidikan Dasar Volume 6 Edisi 2 Desember 2015.

Pratiwi dan Anggraini. 2014. Developing Mind. Makalah diakses pada tanggal 3/6/2015 di http://www.academia.edu/10138647/makalah_developing_mind.

Schunk. D. H. 2012. Learning Theories. Teori-Teori Pembelajaran: Perspektif Pendidikan Edisi Keenam. Yogyakarta: Pustaka Pelajar.

Supardan. D. 2015. Teori-Teori Belajar dan Pembelajaran. Dari Teori Gestalt Sampai Teori Belajar Sosial Jilid II. Bandung: Yayasan Rahardja.

Supardan. D. 2015. Teori-Teori Belajar dan Pembelajaran. Dari Zaman Klasik Sampai Behaviorisme Jilid I. Bandung: Yayasan Rahardja.

Trianto (2011) Model Pembelajaran Terpadu: Konsep, Strategi dan Implementasinya dalam KTSP, Jakarta: Bumi Aksara.

Ukti Lutvaidah (2015). Pengaruh Metode dan Pendekatan Pembelajaran Terhadap Penguasaan Konsep Matematika. Jurnal Formatif 5(3): 279-285, 2015 ISSN: 2088-351X. 